\title{
Pengaruh Biaya Produksi, Lama Usaha, Produktivitas Terhadap Pendapatan Petani Salak Pondoh Di Desa Pronojiwo Kecamatan Pronojiwo Kabupaten Lumajang
}

\author{
(The Effect of Costs Production, Years Of Farming, Productivity to the Income of the \\ Farmers of PondohBark in PronojiwoVillage Pronojiwo Subistrict Lumajang Regency.)
}

\author{
Aditya Purnomo, Moehammad Fathorrazi, Sebastiana Viphindrartin ${ }^{1}$ \\ Ilmu Ekonomi dan Studi Pembangunan, Fakultas Ekonomi dan Bisnis, Universitas Jember (UNEJ) \\ E-mail: sebastianaviphindrartin@gmail.com
}

\begin{abstract}
Abstrak
Penelitian ini bertujuan untuk mengetahui Pengaruh Variabel Biaya Produksi, Lama Usaha, produktivitas Terhadap Pendapatan Petani Salak Pondoh di Desa Pronojiwo Kecamatan Pronojiwo Kabupaten Lumajang. Metode analisis yang digunakan adalah Ordinary Least Square (OLS). Pendapatan sebagai variabel dependen dan biaya produksi, lama usaha dan produktivitas sebagai variabel independen. Berdasarkan hasil analisis OLS menunjukan bahwa variabel biaya produksi dan produktivitas berpengaruh positif dan signifikan terhadap pendapatan petani salak. Sedangkan lama usaha memiliki pengaruh negatif dan tidak signifikan terhadap pendapatan petani salak, seiring dengan berkembangnya jaman informasi dengan mudah didapat, jadi lama tidaknya usaha yang dilakukan tidak menjamin bisa meningkatkan pendapatan petani tersebut.
\end{abstract}

Kata Kunci: Pendapatan, Biaya Produksi, Lama Usaha, Produktivitas.

\begin{abstract}
This study aims to determine the effect of variable of costs production, years of farming, the productivity of the farmers of pondoh bark in Pronojiwo village Pronojiwo subdistrict Lumajang Regency. The analytical method used was Ordinary Least Square (OLS) which the income as the dependent variable and production costs, years of farming and productivity as independent variables. Based on the OLS analysis results, it showed that the variable cost of production and productivity had positive and significant effecton the farmers' income. While the years of farming had a negative effect and no significant effect on farmers' income. It was along with the growing era of information which can easily be obtained, so years of farming done does not guarantee the increasing the farmers' income.
\end{abstract}

Keywords: Income, Cost of Production, Years of Farming, Productivity.

\section{Pendahuluan}

Dalam kehidupan sehari-hari pendapatan adalah hal yang paling penting bagi kehidupan manusia, karena dengan pendapatan yang tersebut kelangsungan hidupnya bisa terpenuhi. Dengan melimpahnya kekayaan alam Indonesia, masyarakat bisa melakukan berbagai aktifitas usaha guna menyambung kelangsungan hidupnya. Indonesia merupakan negara agraris, karena mayoritas masyarakat indonesia mengandalkan sektor pertanian sebagai salah satu mata pencahariannya. Tidak bisa dipungkiri kekayaan alam Indonesia yang melimpah bisa merasa mudah untuk memanfaatkannya. Namun, walaupun kekayaan alam Indonesia sangat melimpah bukan berarti masyarakat dengan mudah bisa mengelolanya. Karena juga dibutuhkan modal yang cukup dan keahlian dalam mengelola kekayaan alam yang ada (Husodo, $2004: 23$ ).

Menurut Mubyarto (1994:4-5) Ilmu Ekonomi adalah Ilmu yang mempelajar perilaku dan upaya serta hubunganhubungan antara manusia, perilaku yang dipelajari bukanlah hanya mengenai perilaku petani dalam kehidupan pertaniannya tetapi mencakup persoalan ekonomi lainnya yang langsung maupun tidak langsung dan yang berhubungan dengan produksi, pemasaran dan konsumsi petani atau kelompok-kelompok petani. Dengan demikian pertanian dapat didefinisi ilmu ekonomi umum yang mempelajari komponen-komponen dan persoalan-persoalan yang berhubungan dengan pertanian secara mikro maupun makro. Pertanian secara mikro disini mencakup proses produksi dan hubungan-hubungan antara faktor-faktor produksi dan hasil produksi. Selanjutnya pertanian secara makro membawa kearah analisa interpretasi dan menghubungka persoalanpersoalan ekonomi makro misalnya persoalan pendapatan nasional, konsumsi, investasi, lapangan kerja dan pembangunan ekonomi.Sektor pertanian memegang peranan penting dari pembangunan nasional. Lumajang adalah salah satu Kabupaten di Jawa Timur yang perekonomiannya bertumpu pada sektor pertanian. Berbagai macam tanaman pertanian dibudidayakan untuk dimanfaatkan sebagai mata pencaharian oleh masyarakat Lumajang. Buah-buahan adalah salah satu produk pertanian lumajang yang dimanfaatkan oleh masyarakat dalam produk pertanian.

Dalam usaha meningkatkan persaingan dengan kemuditas lain, jumlah produksi buah salak pondoh harus ditingkatkan agar pendapatan yang diperoleh petani juga ikut meningkat. Faktor produksi dari fungsi produksi Cobb Douglas merupakan tingkat teknologi, jumlah stok barang modal, dan jumlah tenaga kerja, dari tiga faktor tersebut yang lebih cenderung masuk biaya produksi dalam penelitian ini adalah jumlah stok barang modal dan jumlah tenaga kerja, sedangkan teknologi tidak masuk kedalam penelitian ini dikarenakan tidak diperlukan dalam penelitian ini. Maka dengan adanya penurunan dan peningkatan jumlah stok barang modal dan jumlah tenaga kerja akan berpengaruh terhadap pendapatan.

Dan dalam teori Arthur Lewis menyartakan pengurangan jumlah tenaga kerja tidak akan mengurangi tingkat produksi

1 Corresponding author 
yang ada dan pangsa semua pekerja terhadap produksi berarti sama. Pengalaman kerja akan mempengaruhi tingkat berfikir individu dalam menjalankan pekerjaannya. Cara memanfaatkan faktor produksi secara efisien dan tepat guna meningkatkan produktivitas merupakan gambaran dari pengalaman individu terhadap pekerjaan yang dijalankan. Dengan memanfaatkan wawasan dan pengalaman memungkinkan bisa menciptakann jumlah produktivitas yang sama walaupun jumlah tenaga kerja dikurangi, sehingga dengan pengguanaan tenaga kerja yang efisien bisa meningkatkan pendapatan.

Buah pisang menempati tempat teratas dalam hal produksi. Buah durian mengalami naik turun dalam hal produksi, tahun 2012 adalah produksi tertinggi dibandingkan tahun-tahun selanjutnya. Buah alpukat mengalami penurunan yang sangat tajam dari tahun 2012 ke tahun 2013, penurunannya jelas terlihat sangat signifikan, namun demikian dari tahun ke tahun buah alpukat tidak mengalami penurunan secara beruntun, tetapi produksinya naik secara beruntun pada tahun 2014 dan 2015. Hampir sama dengan buah alpukat, buah nangka juga sempat mengalami penurunan yang sangat tajam dari tahun 2012 ke tahun 2013, tetapi setahun berikutnya produksi buah nangka mampu meningkat secara derastis dan kembali menurun produksinya tahun 2015. Buah pepaya dari tahun ke tahun mengalami naik turun dalam hal produksi buah.

Awal mula adanya salak pondoh di Daerah Pronojiwo bibitnya berasal dari Kabupaten Sleman. Harga buah salak pondoh pada saat panen raya bisa dikatakan relatif lebih murah dikarenakan produksi buah salak pondoh yang melimpah, begitu sebaliknya pada saat panen buruk harga salak pondoh menjadi lebih tinggi dikarenakan buah yang dihasilkan sedikit dibandingkan pada saat panen raya. Mayoritas masyarakat Kecamatan Pronojiwo juga bermata pencaharian sebagai petani salak, hampir di setiap belakang maupun depan rumah terdapat banyak tanaman salak. Tujuan utama dari penelitian ini adalah Untuk mengetahui pengaruh biaya produksi, lama usaha dan produktivitas terhadap pendapatan petani salak di Desa Pronojiwo.

\section{Metode}

\section{Jenis dan Sumber Data}

Jenis penelitian yang adalah penelitian(Explanatory Research) yaitu sebuah penelitian yang menjelaskan hubungan kausal antara variabel-variabel melalui pengujian hipotesis (Asep Hermawan, 2009). Penelitian ini sendiri dilakukan secara sengaja di Desa Pronojiwo Kecamatan Pronojiwo kabupaten lumajang karena sebagian besar penduduknya mayoritas sebagai petani salak pondoh.

\section{Populasi dan Sampel}

Unit analisis dalam penelitian ini yaitu wilayah Desa Pronojiwo, Kecamatan Pronojiwo, Kabupaten Lumajang. Jumlah populasi dalam penelitian ini 400 orang dan diambil sekitar 40 responden sebagai sampel.

\section{Metode Analisis Data}

Untuk menguji hipotesis, variabel-variabel yang mempengaruhi pendapatan petani salak digunakan uji regresi linier berganda diformulasikan sebagai berikut (Wibowo, 2000) :

$$
\mathrm{Y}=a+\mathrm{b}_{1} \mathrm{X}_{1}+\mathrm{b}_{2} \mathrm{X}_{2}+\mathrm{b}_{3} \mathrm{X}_{3}+e
$$

Dimana:

$\mathrm{Y}=$ Pendapatan Petani

$\mathrm{X}_{1}=$ Biaya Produksi

$\mathrm{X}_{2}=$ Lama Usaha

$\mathrm{X}_{3}=$ Hasil Panen

Uji Statistik

Uji statistik terdiri dari uji pengaruh secara bersama-sama (uji F), uji secara parsial (uji t), dan koefisien determinasi $\left(\mathrm{R}^{2}\right)$.

\section{Uji Asumsi Klasik}

Untuk memperjelas dan memperkuat pengaruh dari hasil analisis regresi yang diperoleh maka digunakan uji asumsi klasik. Uji asumsi klasik terdiri atas multikolinieritas, autokorelasi, heteroskedastisitas, dan normalitas.

\section{Hasil dan Pembahasan}

\section{Hasil}

Tabel 1. Hasil analisis regresi

\begin{tabular}{ccccc}
\hline Variable & Coefficient & Std. Error & t-Statistic & Prob. \\
\hline C & 3.114039 & 0.557049 & 5.590247 & 0.0000 \\
X1 & 0.827951 & 0.037316 & 22.18744 & 0.0000 \\
X2 & -0.005608 & 0.010043 & -0.558436 & 0.5804 \\
X3 & 0.106189 & 0.015043 & 7.059017 & 0.0000
\end{tabular}

Nilai konstan sebesar 3.114039 memiliki arti, nilai tersebut menunjukkan bahwa pendapatan petani salak mencapai 3.114039 pertahun apabila variabel biaya produksi, lama usaha, dan hasil panen dianggap konstan

Nilai koefisien variabelbiaya produksi (X1) angka signifikannya berada di bawah probabilitas signifikan 0.05 yaitu sebesar 0.0000 yang memiliki arti bahwa variabel biaya produksi (X1) mempengaruhi pendapatan petani salak secara signifikan. Koefisien regresi untuk biaya produksi (X1) sebesar 0.827951 yang jika biaya produksi (X1) naik sebesar $1 \%$ maka pendapatan salak naik $0.827951 \%$.

Nilai koefisien regresi variabel lama usaha $(\mathrm{X} 2)=-0.005608$ dan berpengaruh tidak signifikan terhadap ppendapatan petani salak.

Nilai koefisien variabel hasil panen (X3) angka signifikannya berada di bawah probabilitas signifikan 0.05 yaitu sebesar 0.0000 yang memiliki arti bahwa variabel hasil panen (X3) mempengaruhi pendapatan petani salak secara signifikan. koefisien Koefisien regresi untuk hasil panen (X3) sebesar 0.106189 yang jika hasil panen (X3) naik sebesar 1\% maka pendapatan salak naik $0.106189 \%$.

\section{Uji Statistik}

\section{Uji Simultan (Uji F)}

Tabel 2. Hasil uji Simultan (Uji F)

\begin{tabular}{lcll}
\hline R-squared & 0.949638 & $\begin{array}{l}\text { Mean } \\
\text { dependent var }\end{array}$ & 16.45944 \\
\hline $\begin{array}{l}\text { Adjusted } \\
\text { squared }\end{array}$ & R- 0.944916 & $\begin{array}{l}\text { S.D. } \\
\text { dependent var }\end{array}$ & 0.333226
\end{tabular}

S.E. of $0.078208 \quad$ Akaike info -2.154449


regression

Sum squared 0.195728

resid

Log

likelihood

F-statistic

201.1315

criterion

Schwarz

$-1.978503$

criterion

Hannan- $\quad-2.093039$

Quinn criter.

Durbin-

Watson stat

1.662021

Prob(F-

0.000000

statistic)

tabel diatas menunjukkan bahwa hasil uji signifikasi simultan (Uji F) diketahui nilai probabilitas $\mathrm{F}_{\text {statistik }}$ sebesar 0.000000 yang berarti nilai probabilitas tersebut llebih kecil dari tingkat signifikansi $\alpha=5 \%$. sehingga $\mathrm{H}_{0}$ ditolak dan $\mathrm{H}_{\mathrm{a}}$ diterima. Artinya secra simultan variabel independen mempengaruhi variabel dependen.

\section{Uji Parameter Individual (Uji t)}

Tabel 3. Hasil Uji Parameter Individual (Uji t)

\begin{tabular}{cccc}
\hline Variabel & Nilai Probabilitas & $\boldsymbol{\alpha}=\mathbf{5 \%}$ & Keterangan \\
\hline$(\mathbf{Y})$ & 0,0000 & 0,05 & Signifikan \\
$(\mathbf{X 1})$ & 0,0000 & 0,05 & Signifikan \\
$(\mathbf{X 2})$ & 0.5804 & 0,05 & $\begin{array}{c}\text { Tidak } \\
\text { Signifikan }\end{array}$ \\
$(\mathbf{X 3 )}$ & 0,0000 & 0,05 & Signifikan \\
\hline
\end{tabular}

Hasil Uji t menunjukkan semua variabel yaitu X1, X2, X3 berpengaruh nyata terhadap $\mathrm{Y}$.

Uji Asumsi Klasik

Uji Multikolinearitas

Tabel 4. Hasil Uji Multikolinearitas

\begin{tabular}{cccc}
\hline & Coefficient & Uncentered & Centered \\
\hline Variable & Variance & VIF & VIF \\
C & 0.310303 & 1826.358 & NA \\
X1 & 0.001392 & 1985.414 & 1.367834 \\
X2 & 0.000101 & 159.6273 & 1.253272 \\
X3 & 0.000226 & 37.49975 & 1.115211
\end{tabular}

Berdasarkan uji tabel multikolinearitas tidak terdapat masalah karena centered VIF tidak ada yang lebih dari 10.

Uji Normalitas

Berdasarkan pengujian diatas menunjukkan bahwa hasil probabilitas $>\alpha$ yaitu $0.234589>0.5$ yang berarti terdistribusi dengan normal.

\section{Pembahasan}

\section{Pengaruh Biaya Produksi Terhadap Pendapatan}

Hasil analisis menunjukkan bahwa biaya produksi berpengaruh signifikan terhadap pendapatan. dengan menggunakan tingkat signifikan $5 \%$ dapat diketahui biaya produksi berpengaruh signifikan dan bertanda positif terhadap pendapatan salak. Tanda positif menujukkan bila biaya produksi bertambah sebesar $1 \%$ maka pendapatan petani akan bertambah sebesar $0.827951 \%$. Ketika biaya produksi yang digunakan sedikit maka produksi petani akan sedikit sehingga berpengaruh terhadap pendapatan petani, begitupun sebaliknya.

Menurut Soekartawi (1995), biaya usahatani dapat dibagi menjadi dua, yaitu biaya tetap dan biaya variabel. Biaya tetap adalah jenis biaya yang besar kecilnya tidak tergantung pada besar kecilnya biaya produksimisalnya sewa atau bunga tanah yang berupa uang. Biaya lain-lain umumnya masuk pada biaya varibel karena besar kecilnya berhubungan dengan besar produksi misalnya pengeluaran-pengeluaran untuk bibit, biaya pengolahan tanah dll.

Hasil tersebut sesuai dengan penelitian terdahulu yang dilakukan oleh Joni Arman Damanik (2014) yang menyatakan bahwa biaya produksi memiliki hubungan yang positif dan berpengaruh signifikan terhadap pendapatan. Biaya usaha merupakan informasi yang bisa memberikan gambaran tentang perbedaan pengeluaran yang telah dikeluarkan oleh masing-masing responden dalam melakukan proses produksi, besar kecilnya biaya usaha yang dikeluarkan petani tergantung kebutuhan yang mereka perlukan. Semakin luas kebun yang dimiliki oleh para petani maka biaya produksi yang dikeluarkan oleh petani juga semakin banyak.

\section{Pengaruh Lama Usaha Terhadap Pendapatan}

Hasil analisis menunjukkan bahwa lama usaha berpengaruh signifikan terhadap pendapatan. dengan menggunakan tingkat signifikan $5 \%$ dapat diketahui lama usaha berpengaruh signifikan dan bertanda negatif terhadap pendapatan salak. Tanda negatif menujukkan bila lama usaha bertambah sebesar $1 \%$ maka pendapatan petani akan turun sebesar $0.005608 \%$. Lama usaha yang dilakukan petani kurang berpengaruh terhadap pendapatan petani, hasil tersebut sesuai dengan penelitian terdahulu yang dilakukan oleh titah Filardi (2014) yang menyatakan lama usaha tidak memiliki hubungan yang positif terhadap petani salak.

Lamanya suatu usaha dapat menimbulkan pengalaman berusaha, dimana pengalaman dapat mempengaruhi pengamatan seseorang dalam bertingkah laku (Sukirno, 1994). Seiring dengan berkembangnya jaman informasi dengan mudah didapat, jadi lama tidaknya usaha yang dilakukan responden belum tentu bisa meningkatkan pendapatan petani tersebut. Responden dapat mendapatkan informasi tentang pengembangan usahanya dengan cara mengikuti penyuluhan-penyuluhan yang diadakan oleh pemerintah atau dinas terkait. Dari sini bisa diambil ilmu yang bisa digunakan oleh responden untuk diterapkan dalam usahanya sehingga dengan bertambahnya wawasan yang dimiliki responden bisa meningkatkan jumlah pendapatannya.

\section{Pengaruh Produktivitas Terhadap Pendapatan}

Hasil analisis menunjukkan bahwa produktivitas berpengaruh signifikan terhadap pendapatan. dengan menggunakan tingkat signifikan $5 \%$ dapat diketahui hasil berpengaruh signifikan dan bertanda positif terhadap pendapatan salak. Tanda positif 
menujukkan bila hasil bertambah sebesar $1 \%$ maka pendapatan petani akan bertambah sebesar $0.106189 \%$.

Produktivitas mengandung arti sebagai perbandingan antara hasil yang dicapai (output) dengan keseluruhan sumberdaya yang digunakan (input). Dengan kata lain bahwa produktivitas memiliki dua dimensi. Dimensi yang pertamaadalah evektivitas yang mengarah pada pencapaian target yang berkaitan dengan kualitas, kuantitas, dan waktu. Kedua yaitu efisiensi yang berkaitan dengan upaya membandingkan input dengan realisasi penggunaanya (Umar, 1998)

Hasil tersebut sesuai dengan penelitian terdahulu yang dilakukan oleh Antonius Y. Luntang (2012) yang menyatakan hasil panen memiliki hubungan yang positif dan berpengaruh signifikan terhadap pendapatan. Hasil panen merupakan informasi yang bisa memberikan gambaran tentang perbedaan perolehan masing-masing responden. Semakin banyak hasil panen yang diperoleh maka semakin banyak juga pendapatan yang akan diterima responden, sehingga hal tersebut bisa mempengaruhi pendapatan yang mereka hasilkan, begitupun sebaliknya jika hasil panen menurun maka pendapatan petani juga ikut menurun.

\section{Simpulan}

Berdasarkan hasil analisis data tentang pengaruh variabel biaya produksi, lama usaha dan hasil panen terhadap petani salak di Desa Pronojiwo Kecamatan Pronojiwo Kabupaten Lumajang dapat disimpulkan sebagai berikut:

Biaya produksi menunjukkan pengaruh positif dan signifikan terhadap pendapatan petani salak di Desa Pronojiwo Kecamatan Pronojiwo Kabupaten Lumajang. Berarti semakin banyak biaya produksi yang dikeluarkan maka pendapatan akan semakin bertambah, begitupun sebaliknya.

Lama usaha menunjukkan pengaruh yang negatif dan tidak signifikan tehadap pendapatan petani salak di Desa Pronojiwo Kecamatan Pronojiwo Kabupaten Lumajang.
Berarti semakin lama menjalani pekerjaan tersebut tidak menjamin untuk meningkatkan pendapatan karena tergantung keterampilan dan pengetahuan yang dimiliki.

Hasil panen menunjukkan pengaruh positif dan signifikan terhadap pendapatan petani salak di Desa Pronojiwo Kecamatan Pronojiwo Kabupaten Lumajang. Berarti semakin banyak hasil panen yang diperoleh maka semakin banyak juga pendapatan yang diperoleh, begitupun sebaliknya.

Biaya produksi merupakan faktor yang paling berpengaruh terhadap pendapatan petani salak Desa Pronojiwo Kecamatan Pronojiwo Kabupaten Lumajang.

\section{Referensi}

Asep Hermawan. (2009). Penelitian Bisnis. Jakarta: PT Grasindo.

BPS. 2016. Kabupaten Lumajang Dalam Angka Tahun 2013. Lumajang: Badan Pusat Statistik

Damanik, Joni Arman. 2014. Analisis Faktor-Faktor Yang Mempengaruhi Pendapatan Petani Padi di Kecamatan Masaran, Kabupaten Sragen. Economics Development Analysis Journal3 (1)

Gujarati, Domar. 2003. Dasar-dasar Ekonometrika. Jakarta. Alih Bahasa. Jakarta.

Husodo.S.Y, dkk. 2004. Pertanian Mandiri. Penebar Swadaya, Jakarta

Mubyarto. 1986. Pengantar Ekonomi Pertanian. LP3ES. Jakarta.

Soekartawi, A Soeharjo, J. L Dillon dan J.B Hardaker. Ilmu Usah tani dan Penenelitian untuk Mengembangkan Petani Kecil. (Jakarta: UI-Press, 1994)

Soekartawi. 2002. Analisis usaha tani. Penerbit Universitas Indonesia (UI Press), Jakarta.

Sadono Sukirno. 2003, Pengantar Teori Mikro Ekonomi, Jakarta : PT Salemba Empat

Sadono Sukirno. Mikro Ekonomi Teori Pengantar, Edisi ketiga, PT. Raja Grafindo Persada, Jakarta, 2005

Sukirno. 2006. Ekonomi pembangunan.proses, masalah dan kebijakan, kencana Prenada Media Group

Umar. H. 1998. Riset Sumber Daya Manusia Dalam Organisasi. Jakarta:PT Gramedia Pustaka Prima

Wibowo, S. 2000. Industri Pemindangan Ikan. Jakrata: Penebar Swadaya. 